\title{
LIABILITY IN ANGLO-AMERICAN LAW FOR DAMAGE DONE BY CHATTELS
}

\begin{abstract}
SCOPE OF STUdY
T HIS study is limited to liability in common-law countries for harm to persons and things caused by chattels, animate and inanimate, through their own force undirected by any human being. The energy which generates the harmful force may be kinetic or potential but it is not directly supplied or released by any responsible agency. This limitation excludes harm resulting from the activity of persons who employ chattels as a means to accomplish harm to others or to things or who so utilize chattels in the conduct of their activity that such harm results. Therefore, the study does not include the liability of those who use motor cars, firearms, explosives, or other things in such a manner and for such a purpose as to subject them to liability in tort whether for their intentional or negligent misconduct or because they have engaged in an activity so ultrahazardous as to render them liable for the accidental miscarriage thereof. Neither does it include vicarious liability in any form. Within its scope, however, is included liability for trespasses on land by domestic animals and personal injuries by domestic and wild animals; harm caused by explosives or combustibles not intentionally or negligently discharged or ignited by a human being; and the escape of substances which, while ordinarily harmless, become potentially harmful because collected in unusual quantities in artificial receptacles.
\end{abstract}

\section{Trespassing Animals}

By English common law the possessor of certain domestic animals becomes liable if they escape from his premises and intrude upon the land of another. ${ }^{1}$ His liability does not depend upon the harmful consequences of the intrusion. The action is one for the trespass and requires no proof of damage. The liability, however, includes all harm legally resulting

${ }^{1}$ Anonymous Case, 12 Hen. VII, Keilway, 3b; Cox v. Burbridge, (1863) 3 C. B. (N.S.) 430 ; Page v. Hollingsworth, (1885) 7 Ind. 317 ; Pittsburgh etc. R. Co. v. Stuart, (1880) 71 Ind. 500; Stackpole v. Healy, (1819) 16 Mass. 33; Locke v. St. Paul etc. R. Co., (1876) 15 Minn. 350; Tewksbury v. Bucklin, (1835) 7 N. H. 518; Tonawanda R. Co. v. Munger, (1848) 5 Denio 255, 49 Am. Dec. 239; Gresham v. Taylor, (1874) 51 Ala. 505; D'Arcy v. Miller, (1877) 86 Ill. 102 ; McKee v. Trisley, (1924) 311 Ill. 536, 143 N. E. 69; Bileu v. Parsley, (1889) 18 Ore. 47; Tennessee Chemical Co. v. Hemry, (1904) 114 Tenn. 152; Hurd v. Rutland R. Co., (1853) 25 Vt. 116. 
from the intrusion. ${ }^{2}$ This liability in no way depends upon a lack of care or diligence on the part of the possessor. He is liable although he employs all the care and diligence which a reasonable man would think adequate to prevent the escape of the animal. Liability is entirely independent of fault. The possessor takes the risk of the inadequacy of his precautions. ${ }^{3}$

Although it was said in a leading case that this liability is imposed upon the owner of any animal "in which by law the right of property can exist", ${ }^{4}$ it is clear that it is confined to a very few types of domestic animals. The rule is applied to horses, ${ }^{5}$ cattle, ${ }^{6}$ hogs, ${ }^{7}$ and sheep. ${ }^{8}$ It is not applicable to dogs ${ }^{9}$ and cats $^{10}$ but it is applicable to domestic fowls. ${ }^{11}$ The rule does not apply to a possessor of animals who is properly driving

2 Decker v. Gammon, (1857) 44 Me. 322, 69 Am. Dec. 99; Morgan v. Hudnell, (1895) 52 Ohio St. 552, 40 N. E. 716, 27 L. R. A. 862, 49 Am. St. 741; Angus v. Rain, (1820) 5 N. J. L. 815, 8 Am. Dec. 626; McKee v. Trisler, (1924) 311 Ill. 536, 143 N. E. 69, 33 A. L. R. 1298 ; Ellis v. Loftus Iron Co., (1874) L. R. 10 C. P. 10. See 32 Harvard Law Review (1919), at p. 420.

Such liability, however, is only for "consequential" damages. If there is no trespass to land, there is no liability at all under this rule. See Warrington L. J. in Manton v. Brocklebank, [1923] 2 K. B. 212, 226, with which compare Ellis v. Loftus Iron Co., (1874) L. R. 10 C. P. 10. It is essential to prove scienter. Cf. W. T. S. Stallybrass, Salmond on Torts (ed. 8, London, 1934), at p. 563.

${ }^{3}$ The rule is phrased by the American Law Institute in its Tentative Draft of the Restatement of Torts as follows: "Except as stated in $\S 505$ [which relates to a possessor of livestock driven on a public highway and straying therefrom], a possessor of livestock which stray upon the land of another is liable for their intrusion and for any harm done while upon the land to its possessor or a member of his household although the possessor of the livestock exercised the utmost care to prevent them from doing so" (Tentative Draft, no. 12, § 504).

${ }^{4}$ Cox v. Burbridge (supra, n. 1).

${ }^{5}$ Ellis v. Loftus Iron Co., (1874) L. R. 10 C. P. 10; Jones v. Witherspoon, (1860) 52 N. Car. 555; Bulpit v. Mathews, (1893) 145 Ill. 345.

${ }^{6}$ Tereksbury v. Bucklin, (1835) 7 N. H. 518; Laws v. North Car. R. Co., (1869) 52 N. Car. 468.

${ }^{7}$ Walters v. Stacey, (1905) 122 Ill. App. 658; Mixner v. Lighthall, (1852) 13 I11. 609.

8Bileu v. Parsley, (1889) 18 Ore. 47, 21 Pac. 934.

${ }^{9}$ Brozen v. Giles, (1823) 1 C. \& P. 118; Fisher v. Badger, (1902) 95 Mo. App. 289, 69 S. W. 26; Van Etten v. Norges, (1908) 112 N. Y. S. 888.

${ }^{10}$ Buckle v. Holmes, [1926] 2 K. B. 125, 54 A. L. R. 89. See, however, a criticism in 13 Cornell Law Quarterly (1927), at p. 150.

${ }_{11}^{1}$ Adams Bros. v. Clark, (1920) $189 \mathrm{Ky} .279,224$ S. W. 1046; McPherson v. James, (1896) 69 Ill. App. 337; Lapp v. Stanton, (1911) 116 Md. 197, 81 Atl. 675, Ann. Cas. 1913, C. 755. 
them along a public highway $;^{12}$ in such a case his liability will depend upon his lack of care in restraining them. ${ }^{13}$

Liability is based upon the possession of the animal rather than its ownership. One is liable for the escape of an animal from his own land if he is in the possession of the animal, although it belongs to a third person. ${ }^{14}$ On the other hand, he is not liable for the escape from his land of an animal in the possession of a third person although he knows of its presence on his land or, indeed, has given his consent thereto. ${ }^{15}$ So too, one is liable for the escape of animals in his possession although they escape from the land of a third person. ${ }^{16}$ But the owner of animals is not liable for their escape even from land of which he is in possession, if they were in the possession of a third person at the time of their escape. ${ }^{17}$

In the United States the original rule of the common law has had a

${ }^{12}$ Tillett v. Ward, (1882) L. R. 10 Q. D. 17 ; Stackpole v. Healy, (1819) 16 Mass. 33; Wood v. Snider, (1907) 187 N. Y. 28, 79 N. E. 858; Erdman v. Gottshall, (1899) 9 Pa. Super. 295 ; Cool v. Cromet, (1836) 13 Me. 250 ; Goodwyn v. Cheveley, (1859) 4 Hurl. \& N. 631. This immunity is available only as against an occupier of land abutting on the highway over which the animals are being driven (Wood v. Snider, (1907) 187 N. Y. 28, 79 N. E. 858, 12 L. R. A. (N.S.) 912).

${ }^{13}$ The non-liability of the possessor of animals which stray from the highway exists only when the animals are being properly driven thereon for a legitimate purpose. It does not exist with respect to a possessor who permits his stock to run at large or graze along the highway (Stackpole v. Healy, (1819) 16 Mass. 33, 8 Am. Dec. 121; Avery v. Maxwell, (1827) 4 N. H. 36; Dovaston v. Payne, (1795) 2 H. B1. 527).

${ }^{14}$ Moulton v. Moore, (1884) 56 Vt. 700 ; Tewksbury v. Bucklin, (1835) 7 N. H. 518; Rossell v. Colton, (1858) 31 Pa. 525; Van Slyck v. Snell, (1872) 6. Lans. (N. Y.) 299 ; Blaisdell v. Stone, (1881) 60 N. H. 507; Sheridan v. Bean, (1844) 8 Metc. (Mass.) 284. See Bacon's Abridgement, Tit. Tresp. G. 2 ; Comyns Digest, Tit. Tresp. B.

${ }^{15}$ See Tewksbury v. Bucklin, (1835) 7 N. H. 518; Sturtevant v. Merrill, (1851) $33 \mathrm{Me}$. 62. Certainly, the possessor of land is not liable because another's cattle stray upon and then away from his land to the land of a third person ( $P o o l$ v. Alger, (1859) 77 Mass. 489; Cook v. Morea, (1870) 33 Ind. 497; Lawrence v. Combs, (1858) 37 N. H. 331).

16"Liability is imposed upon the possessor of the livestock and not upon the possessor of the land on which they are kept. Therefore, their possessor is equally liable where as licensee or even as trespasser he keeps them upon land in possession of a third person" (Restatement of Torts, Tentative Draft, no. 12, $\S 504$, comment b).

${ }^{17}$ Rossell v. Colton, (1858) $31 \mathrm{~Pa}$. 525; Reddick v. Newburn, (1882) $76 \mathrm{Mo}$. 423; Mott v. Scott, (1905) 35 Colo. 68, 83 Pac. 779; Ward v. Brozen, (1872) 64 Ill. 307. Contra, Sheridan v. Bean, (1844) 8 Metc. 284, 41 Am. Dec. 507. As to the split of common-law authority on this point, the American Law Institute, in its Tentative Draft of the Restatement of Torts, has adopted the rule stated in the text. See Tentative Draft, no. 12 , § 504, comment $\mathrm{f}$. 
checketed career. In a number of states the rule has been rejected entirely on the grounds that it was inappropriate and unsuitable to local conditions. ${ }^{18}$ This has occurred mostly in those sections of the country in which cattle-raising was an important industry. On the other hand, the rule has been adopted in a number of states in which, by reason of their heavy population, this industry has been subordinate to manufacturing and the agricultural development of small farms. Thus, the English rule has been held to prevail in Massachusetts, ${ }^{10}$ New Hampshire, ${ }^{20}$ New York, ${ }^{21}$ Michigan, ${ }^{22}$ Indiana, ${ }^{23}$ and Vermont ${ }^{24}$ whereas it has been rejected in Iowa, ${ }^{25}$ Nebraska, ${ }^{26}$ Colorado, ${ }^{27}$ California, ${ }^{28}$ Arkansas, ${ }^{28}$ Montana, ${ }^{30}$ Texas, ${ }^{31}$ Wyoming, ${ }^{32}$ Georgia, ${ }^{33}$ Mississippi, ${ }^{34}$ and Missouri. ${ }^{35}$ In some states first one rule then another has prevailed, ${ }^{36}$ and in others, legislation has repudiated the rule, ${ }^{37}$ or re-enacted it. ${ }^{38}$

${ }^{18}$ Perhaps the best discussion by a court which considers carefully the rule and rejects it as unsuitable to local conditions is to be found in the opinion of Cobb $\mathrm{J}$. in Delaney v. Erickson, (1880) 10 Nebr. 492, 6. N. W. 600, 35 Am. Rep. 487.

${ }^{10}$ Stackpole v. Healy, (1819) 16 Mass. 33.

${ }^{20}$ Tewksbury v. Bucklin, (1835) 7 N. H. 518.

${ }^{21}$ Tonazuanda R. Co. v. Munger, (1848) 5 Denio 255, 49 Am. Dec. 239;

Harrison v. M'Clellan, (1909) 118 N. Y. S. 513.

22Johnson v. Wing, (1854) 3 Mich. 163.

${ }^{23}$ Page v. Hollingsworth, (1855) 7 Ind. 317; Pittsburg etc. R. Co. v. Stuart, (1880) 71 Ind. 500.

${ }^{24}$ Hurd v. Rutland R. Co., (1853) 25 Vt. 116.

${ }^{25}$ Wagner v. Bissell, (1856) 3 Iowa 396.

${ }^{26}$ Delaney v. Erickson, (1880) $10 \mathrm{Nebr}$. 492, 6 N.W. 600, 35 Am. Rep. 487.

${ }^{27}$ Morris v. Fraker, (1880) 5 Colo. 425.

${ }^{28}$ Waters v. Moss, (1859) 12 Calif. 535.

${ }^{29}$ Little Rock etc. R. Co. v. Finley, (1881) 37 Ark. 562.

30 Blinhorn v. Griswold, (1902) 27 Mont. 79.

${ }^{31}$ Pace v. Potter, (1893) 85 Tex. 473, 22 S. W. 300 ; Land Co. v. McClelland, (1893) 86 Tex. 179.

${ }^{32}$ Cosfrieff v. Miller, (1901) 10 Wyo. 190.

${ }^{33}$ Macon R. Co. v. Lester, (1860) 30 Ga. 911.

${ }^{34}$ Vicksburg R. Co..v. Patton, (1856) 31 Miss. 156.

${ }^{35}$ Bradford v. Floyd, (1883) 80 Mo. 207.

${ }^{36}$ Cf. Gresham v. Taylor, (1874) 51 Ala. 504, with Wilhite v. Speakman, (1885)

79 Ala. 400, and Sprague v. Fremont R. Co., (1888) 6 Dak. 86, with Bostrevick v. Minnesota R. Co., (1892) 2 N. Dak. 440.

${ }^{37}$ Studwell v. Ritch, (1841) 14 Conn. 292; Chase v. Chase, (1880) 15 Nev. 259;

Poindexter v. May, (1900) 98 Va. 145; Blaine v. Chesapeake etc. R. Co., (1876)

9 W. Va. 252.

${ }^{38} \mathrm{McKee}$ v. Trisler, (1924) 311 Ill. 536, 143 N. E. 69; Bulpit v. Mathews, (1893) 145 Ill. 345, 34 N. E. 525, 22 L. R. A. 55; Sloan v. Hubbard, (1878) 34 Ohio St. 583. 
In a number of states statutes have qualified the rule by requiring the possessor of animals to fence them in as a condition to immunity, ${ }^{39}$ or by requiring land occupiers to fence out his neighbour's animals as a condition to recovery, ${ }^{40}$ or by providing a procedure whereby local officials may assign certain portions of the boundary line between contiguous tracts of land to their respective possessors for fencing. ${ }^{41}$ These statutes permitting boundary-line fences have no effect upon liability until assignment and allocation of fencing obligations have been made by the proper official..2 Under such a statute the possessor of land who complies with the order of assignment may recover for intrusions by his neighbour's cattle. ${ }^{43}$ The occupier who does not so comply may not recover unless the cattle were owned by one other than the adjoining land-owner. ${ }^{44}$ If neither complies it seems that a recovery may be obtained, especially if, aside from the statute, the original common-law rule prevailed.45

The rationale of the English rule was at first based upon the fiction of identity of the possessor with the beast and the wrongful conduct of the animal..6 "Where my beasts of their own wrong", says an anonymous

${ }^{39}$ See Barber v. Mensch, (1893) $157 \mathrm{~Pa}$. 390, 27 Atl. 708; Frederick v. White, (1874) 73 Ill. 590.

${ }^{40}$ Chase v. Chase, (1880) 15 Nev. 259; Heald v. Grier, (1882) 12 Mo. App. 556; Moore v. White, (1870) 45 Mo. 206; Wilhite v. Speakman, (1885) 79 Ala. 400 ; Woody v. Purdy, (1852) 20 Ala. 379; Comerford v. Dupuy, (1861) 17 Calif. 308; Frazier v. Nortinus, (1871) 34 Iowa 82; Page v. Hollingsworth, (1855) 7 Ind. 317; Clark v. Stipp, (1881) 75 Ind. 114; Darling v. Rogers, (1871) 7 Kans. 592; Prather v. Rewr, (1880) 23 Kans. 627; Britton v. Van Camp, (1810) 3 N. J. L. 240; Gooch v. Stephenson, (1836) $13 \mathrm{Me}$ 371; Gregg v. Gregg, (1867) $55 \mathrm{~Pa} .227$.

${ }^{41}$ Cozvls v. Balzer, (1867) 47 Barb. 562; Coxe v. Robbins, (1828) 9 N. J. L. 384 ; Bradbury v. Gilford, (1865) $53 \mathrm{Me}$. 99; Sturtevant v. Merrill, (1851) $33 \mathrm{Me}$. 62 ; Coxe v. Cavanaugh, (1872) 44 Vt. 268; Walters v. Stacy, (1905) 122 Ill. App. 658; Brown v. Sams, (1907) 119 Tenn. 677, 109 S. W. 513; Pool v. Alger, (1858) 11 Gray 489; Kobayashi v. Strangeway, (1911) 64 Wash. 36, 116 Pac. 461 ; Baynes v. Chastain, (1879) 68 Ind. 376; Hine v. Munson, (1864) 32 Conn. 219.

42 Thayer v. Arnold, (1842) 4 Metc. 589; Tewksbury v. Bucklin, (1835) 7 N. H. 518; Webber v. Closson, (1852) 35 Me. 26; Coxe v. Robbins, (1828) 9 N. J. L. 384 ; Rust v. Low, (1809) 6 Mass. 90.

${ }^{43}$ Walters v. Stacey, (1905) 122 Ill. App. 658; Brozen v. Sams, (1907) 119 Tenn. 677.

${ }^{44}$ Wilder v. Wilder, (1866) 38 Vt. 678; Stafford v. Ingersol, (1842) 3 Hill 38; Chambers v. Mathews, (1841) 18 N. J. L. 368; Lord v. Wormwood, (1849) $29 \mathrm{Me}$. 282 ; Jackson v. Rutland etc. R. Co., (1853) 25 Vt. 150; York v. Davis, (1840) 11 N. H. 241; D'Arcy v. Miller, (1877) 86 Ill. 102; Cowles v. Balzer, (1867) 47 Barb. 562.

${ }^{45}$ Roach v. Lawrence, (1883) 56 Wisc. 478; Myers v. Dodd, (1857) 9 Ind. 290.

46 "Its origins may perhaps be found in a form of noxal liability. It was also sometimes treated as a kind of vicarious liability: 'qui facit per equum' or 'equam' 
case of the reign of Henry VII, 47 "without my will and knowledge break into another's close, I shall be punished, for I am the trespasser with my beasts." Blackstone purported to find grounds for the rule in the negligence of the possessor. ${ }^{48}$ Modern analysis refers legal responsibility to the principle of liability without fault ${ }^{40}$ of which it seems all instances of liability for damage caused by chattels are further illustrations.

\section{Harm to Persons by Dangerous Animals}

"The law of England", observed a distinguished judge,,50 "recognizes two distinct classes of animals; and as to one of those classes it cannot be doubted that a person who keeps an animal belonging to that class must prevent it from doing injury, and it is immaterial whether he knows it to be dangerous or not. As to another class, the law assumes that animals belonging to it are not of a dangerous nature, and anyone who keeps an animal of this kind is not liable for the damage it may do unless he knew that it was dangerous." This distinction is the foundation of the common law as to liability for harm other than trespass to land caused by animals in possession. The distinction between domestic animals and animals ferae naturae, "as a lion, a bear, a wolf, yea, an ape or monkey", is noted as well established in Hale's Pleas of the Crown. ${ }^{51}$ The possessor of a wild animal must keep it at his peril ; if it escapes and attacks another his innocence of fault will be no defence..$^{52}$ It is immaterial that he believed

or 'per bovem facit per se', a doctrine emphatically rejected by Lord Sterndale M. R. in Manton v. Brocklebank, [1923] 2 K. B. pp. 218-220. It is now based upon the proprietary ground as involving an interference with possession, an application of the maxim 'sic utere tuo ut alienum non laedas'. See Holdsworth, H. E. L. viii, 470-1, Bohlen, Studies, pp. 354-360" (W. T. S. Stallybrass, Salmond on Torts (ed. S, London, 1934), at p. 560, n. y).

${ }^{47}$ Anonymous Case, Y. B. 12 Henry VII. Keilway $3 \mathrm{~b}$.

${ }^{48}$ Commentaries, 3, at p. 211. See also T. A. Street, Foundations of Legal Liability (Long Island, 1906), vol. I, at p. 52.

${ }^{49}$ See supra, n. 46.

50Lord Esher, in Filburn v. Peoples Palace Co., (1890) L. R. 25 Q. B. D. 258. 511 Hale's Pleas of the Crown, 439, part I, c, 33.

${ }^{52}$ Filburn v. Peoples Palace Co., (1890) L. R. 25 Q. B. D. 258; May v. Burdett, (1846) 9 Q. B. 101; Vredenburg v. Behan, (1881) 33 La. Ann. 627; Marquet v. La Duke, (1896) 96 Mich. 596, 55 N. W. 1006; Copley v. Wills, (1913) 152 S. W. 830 (Tex. Civ. App.) ; Hayes v. Miller, (1907) 150 Ala. 621, 43 So. 818, 11 L. R. A. (N.S.) 748, 124 Am. St. Rep. 93; Opelt v. Al. G. Barnes Co., (1919) 41 Calif. App. 776, 183 Pac. 241 ; Jackson v. Baker, (1904) 24 App. D. C. 100; Warner v. Chamberlain, (1884) 7 Houst. (Del.) 18, 30 Atl. 638; Phillips v. Garner, (1914) 106 Miss. 828, 64 So. 735; Muller v. McKesson, (1878) 73 N. Y. 195, 29 Am. Rep. 123; Andrew v. Kilgour, (1910) 19 M. R. 545; Shaw v. McCreary, (1890) 19 O. R. 39; Conner v. Princess Theatre, (1912) 27 O. L. R. 466, 10 D. L. R. 143. 
that he had succeeded in taming the animal or that he had taken every possible precaution against its escape..$^{53}$ An exception is to be noted where by statute the defendant is authorized or obligated to keep the animal. This statutory privilege is available to relieve from the rules of strict liability a zoological society, park, or other organization specifically authorized to maintain wild animals for educational purposes. ${ }^{54}$

The same liability is imposed by the common law upon one who harbours a domestic animal if, but not unless, he knew or had reason to know that the particular domestic animal was dangerous. ${ }^{55}$ In such a case he is subject to liability for its escape and subsequent attck upon one other than a trespasser, in spite of reasonable precautions to confine the animal. ${ }^{56}$ Thus, in the case of wild animals the dangerous character of

${ }^{53}$ Andrew v. Kilgour, (1910) 19 M. R. 545; Filburn v. Peoples Palace Co., (1890) L. R. 25 Q. B. D. 258. But note the contrary dictum in Conner v. Princess Theatre, (1912) 27 O. L. R. 466, 10 D. L. R. 143.

${ }^{54}$ Guzzi v. New York Zoological Soc., (1920) 192 App. Div. 263, 182 N. Y. S. 257, aff. (1922) 233 N. Y. 511, 135 N. E. 897; Jackson v. Baker, (1904) 24 App. D. C. 100. An analogous privilege has been recognized in cases involving the rule of Rylands v. Fletcher. See Madras R. Co. v. Carvetinagarum, (1874) 30 L. T. R. 770 ; Green v. Chelsea Waterworks Co., (1894) 70 L. T. R. 547. Sir John Salmond's criticism of this restriction seems hardly justifiable (see ed. 7, at pp. 365-6). It has been abandoned by Dr. Stallybrass in his 8th edition of that work.

${ }^{55}$ Burton v. Moorhead, (1881) 8 Sess. Cas. (ser. 4) 892 ; Kittredge v. Elliot, (1844) 16 N. H. 77, 41 Am. Dec. 717; Rider v. White, (1875) 65 N. Y. 54, 22 Am. Rep. 600; Goode v. Martin, (1881) 57 Md. 606, 40 Am. Rep. 448; Montgomery v. Koester, (1883) 35 La. Ann. 1091, 48 Am. Rep. 253 ; Evans v. McDermott, (1886) 49 N. J. L. 163, 6 Atl. 653, 60 Am. Rep. 602 ; Buckley v. Leonard, (1847) 4 Denio 500; Cockerham v. Nixon, (1850) 11 Ired. (N. Car.) 269; Murphy v. Preston, (1887) 5 Mackey (D. C.) 514 ; Eddy v. Union R. Co., (1903) 25 R. I. 451, 56 At1. 677; Le Forest v. Tolman, (1875) 117 Mass. 109; Reed v. Southern Express Co., (1894) 95 Ga. 108, 22 S. E. 133; Morgan v. Hudnell, (1895) 52 Ohio St. 552, 40 N. E. 716; Dufer v. Cully, (1871) 3 Ore. 377; Scott v. Grover, (1884) 56 Vt. 499 ; Slinger v. Henneman, (1875) 38 Wisc. 504; Harris v. Williams, (1932) 15 Pac. (2) 580 (Okla.) ; Peltus v. Wrvyel, (1920) 225 S. W. 191 (Tex. Civ. App.).

${ }^{56}$ In a distinct minority of cases, negligence on the part of the possessor of the animal seems necessary to liability. See Worthen v, Love, (1888) $60 \mathrm{Vt}$. 285, 14 At1. 461 ; Hayes v. Smith, (1900) 62 Ohio St. 161, 56 N. E. 879 ; Vaughn v. Miller Bros. "101" Ranch Wild West Show, (1931) 109 W. Va. 170, 153 S. E. 289; De Gray v. Murray, (1903) 69 N. J. L. 458, 55 Atl. 237; Fake v. Addicks, (1890) 45 Minn. 37,47 N. W. 450.

In some situations not falling within the rules of strict liability, negligence, of course, may make the possessor of an animal liable. Thus, a domestic animal although not abnormally dangerous, may have known propensities to inflict harm under certain circumstances. Reasonable precautions in such cases must be taken to prevent harm to others. See Parsons v. Manser, (1903) 119 Iowa 88, 93 N. W. 86, 62 L. R. A. (N.S.), 132, 97 Am. St. Rep. 283, with note collecting cases 
the animal as a class is the risk against which the law affords protection. In the case of domestic animals it is the dangerous character of the particular animal and the scienter of its possessor that are the bases of liability. ${ }^{57}$

Here again attempts have been made to regard liability as predicated upon fault. One of the most eminent of American judges, the author of a classic treatise on torts, ascribed liability to this principle. ${ }^{58}$ It is clear, however, that this analysis will not do. Negligence at common law consists of an activity which subjects another to a risk of harm which it is reasonable to create or, in cases of certain definite relationships, the reasonable failure to adopt measures to prevent harm to another. ${ }^{58}$ In both aspects of negligence it is the unreasonableness of the risk, the impropriety or social undesirability of the defendant's conduct, whether of act or omission, which is the liability-creating factor. This unreasonableness consists either in the impropriety of the conduct or the improper manner in which it is carried on. Liability at common law for keeping dangerous animals is independent of either of these factors. Thus, it is not improper nor undesirable in many circumstances to harbour wild beasts. Their confinement for exhibition purposes performs desirable functions of education and wholesome entertainment. If such activities are conducted in a proper manner with reasonable precautions, there is no basis for the imputation of negligence merely because the precautions turn out to be inadequate. So too, the keeping of ferocious dogs and other domestic animals for the purpose of protecting human life and property is in many instances not only justifiable but necessary. If care is employed to warn innocent intruders and to prevent the escape of such animals, there is no foundation for a charge of negligence. Modern writers and judges again refer this type of liability to the principle of liability without fault.

Like the case of intrusion by a domestic animal, liability depends upon its possession, rather than its ownership or the premises on which it is kept, ${ }^{60}$ unless one, who as occupier and possessor by tolerating dogs on liability for negligently maintaining beehives near the highway. See also Earl v. Van Alstine, (1850) 8 Barb. (N. Y.) 630; Ammons v. Kellogg, (1925) 137 Miss. 551,102 So. 562, and annotation in 39 A. L. R. 360 following.

${ }^{57}$ See Burton v. Moorhead, (1881) 8 Sess. Cas. (ser. 4) 892 ; May v. Burdett, (1846) 9 Q. B. 101.

${ }^{58}$ Cooley on Torts (ed. 2), at pp. 410-1.

${ }^{59}$ See Restatement of Torts, vol. II, $\S \S 282,283$, and 284 . See also H. T. Terry, "Negligence" in 29 Harvard Law Rcviece (1915), at p. 40; Selected Essays on the Law of Torts (Harvard, 1924), at p. 267.

${ }^{80}$ Burch v. Lowary, (1906) 131 Iowa 719. 109 N. W. 282; Auchmuty v. Ham, 
or other animals thereon, fails to exercise that care and caution for the safety of his invitees which the common law enjoins. ${ }^{61}$ The bailee of an animal is subject to the same rules as the owner who keeps an animal on his premises. Thus, a carrier in possession of an animal for transportation is subject to the rule of strict liability, although there seems to be a division of the meagre authority available. ${ }^{62}$ On the other hand, the owner is not subject to the rule of strict liability if the animal escapes or causes injury while in the possession of the bailee, although, of course, he may be liable if he has negligently failed to warn the bailee of the dangerous propensities of a domestic animal. This is true whether the person harmed is the bailee himself or a third person. ${ }^{63}$

Although at common law both in England and the United States, scienter is required to subject the possessor of a domestic animal to liability for harm to persons in the absence of trespass to land, it is to be noted that if there is such a trespass, even it seems by an animal for whose mere trespass there was no liability, the possessor is subject to liability for harm to persons or chattels although there is an absence of scienter. ${ }^{64}$ (1845) 1 Denio (N. Y.) 495; Frammell v. Little, (1861) 16 Ind. 251; Snyder v. Patterson, (1894) 161 Pa. 98, 28 Atl. 1006; Slater v. Sorge, (1911) 166 Mich. 173, 131 N. W. 565; McIntire v. Leland, (1918) 228 Mass. 348, 118 N. E. $665 ;$ McLoughlin v. Kemp, (1900) 152 Mass. 7, 25 N. E. 18; Miller v. Reeves, (1918) 101 Wash. 642, 172 Pac. 815; Whallen v. Wetzell, (1884) 6 Ky. L. Rep. 50.

The cases involving liability of a married woman for injuries inflicted by a dog owned by her husband but kept on land owned by her may mostly be properly regarded as cases of joint keeping or harbouring since the wife has consented to or approved thereof. See Shaw v. McCreary, (1890) 19 O. R. 39; Hugron v. Statton, (1900) Rap. Jud. Quebec 18 C. S. 200 ; Quiltie v. Battie, (1892) 135 N. Y. 201, 32 N. E. 47. In some cases, negligence may be shown (Hopper v. Crocker, (1919) 85 So. 843 (Ala. App.)).

${ }^{61}$ See Andrews v. Jordan Marsh Co., (1933) 283 Mass. 158, 186 N. E. 71; Gallagher v. Kroger Grocery etc. Co., (1925) 272 S. W. 1005 (Mo. App.); Smith v. Great Eastern R. Co., (1866) L. R. 2 C. P. 4. But see Westcott v. Seattle R. etc. Co., (1906) 41 Wash. 618, 84 Pac. 588.

${ }^{62}$ Holt v. Leslie, (1915) 116 Ark. 433, 173 S. W. 191. But see Trinity etc. $R$. Co. v. O'Brien, (1898), 18 Tex. Civ. App. 690, 46 S. W. 389, in which liability was conditional on negligence, with both of which compare The Lord Derby, (1883) 4 Woods 247, 17 Fed. 265.

${ }^{63}$ White v. Steadman, [1913] 3 K. B. 340; Lunch v. Richardson, (1895) 163 Mass. 160, 39 N. E. 801, 47 Am. St. Rep. 444; Hosmer v. Carney, (1920) 228 N. Y. 73, 126 N. E. 650 ; Artificial Ice Co. v. Martin, (1936) 198 N. E. 446, holding that contributory negligence is a defence. See also 20 Columbia Law Review (1920), at p. 89.

${ }^{64}$ Decker v. Gammon, (1857) $44 \mathrm{Me}$ 322, 69 Am. Dec. 99; Field v. Viraldo, (1919) 141 Ark. 32, 216 S. W. 8; Page v. Hollingsworth, (1855) 7 Ind. 317; Assgus v. Radin, (1820) 5 N. J. L. 815, 8 Am. Dec. 626; Morgan v. Hudnell, (1895) 52 
In a large number of jurisdictions, statutes have eliminated the necessity for scienter in any event, especially with reference to harm done by dogs, thus putting the possessor of such animals in the same position, as to risk of liability, as the possessor of wild beasts. ${ }^{65}$

\section{Escape of Dangerous Substances}

The great case of Rylands v. Fletcher ${ }^{68}$ firmly established in English law the rule that one who collects for his own purposes upon his own land

Ohio St. 552, 40 N. E. 716; 49 Am. St. Rep. 741; Mosher v. Beale, (1890) 43 Fed. 358; Malone v. Knowolton, (1891) 39 N. Y. S. R. 901; Smith v. Garnera, (1920) 113 Wash. 368, 194 Pac. 375; Lee v. Burk, (1885) 15 Ill. App. 651; Lee wv. Riley, (1865) 18 C. B. N. S. 722, 144 E. R. 629 ; Ellis v. Loftus Iron Co., (1874) L. R. 10 C. P. 10.

Some cases apply a different rule if the plaintiff failed to maintain a statutory fence as a result of which the animal came upon his premises. See Perry v. Cobb, (1903) 4 Ind. Terr. 717, 76 S. W. 289; Scott v. Grover, (1884) 56 Vt. 499, 48 Am. Rep. 814. And some cases seem to turn upon the nature of the basis for the plaintiff's claim (the form of action) whether for trespass to land with consequential damages or an action directly to recover for the harm sustained. See Beckett v. Beckett, (1871) 48 Mo. 396; Dufer v. Cully, (1871) 3 Ore. 377; Low v. Barnes, (1911) 30 Okla. 15, 118 Pac. 389; Dunckle v. Kocker, (1851) 11 Barb. 387. But see Decker v. Gammon, (1857) $44 \mathrm{Me}$.322, $69 \mathrm{Am}$. Dec. 99.

${ }^{65}$ These statutes are sometimes in general terms making the owner of the dog or other animal designated liable for harm done and sometimes more specific, making the owner liable for particular harm, e.g., killing of sheep. Almost without exception, these statutes, although not expressly so stipulating, are interpreted to eliminate the requirement of scienter (Brent v. Kimball, (1871) 60 Ill. 211, 14 Am. Rep. 35; Stuber v. Gammon, (1896) 98 Iowa 228, 67 N. W. 105; Forsythe v. Kluckbohn, (1913) 161 Iowa 267, 142 N. W. 225; Ballou v. Humphrey, (1811) 8 Kans. 219; Bush v. Wathen, (1891) $104 \mathrm{Ky} .548,47$ S. W. 599; Carroll v. Marcoxx, (1903) 98 Me. 259, 56 At1. 848; Galvin v. Parker, (1891) 154 Mass. 346, 28 N. E. 244; Trampen v. Verhage, (1884) 54 Mich. 304, 20 N. W. 53; Kingston v. Towele, (1868) 48 N. H. 57; Jacobsmeyer v. Poggemoeller, (1892) 47 Mo. App. 560; Kleybolte v. Buffon, (1913) 89 Ohio St. 61,105 N. E. 192; Cockfield v. Singletary, (1868) 15 Rich. L. (S. Car.) 240).

These statutes are generally construed strictly. Thus, if the statute is applicable to "owners" of dogs, it applies only to owners and not to others who harbour a dog (Alexander v. Crosby, (1909) 143 Iowa 50, 119 N. W. 717; Wormley v. Gregg, (1872) $65 \mathrm{III.} 251$ ). They are not applicable to harm done by a mad dog, since this risk was not the danger against which the statute was directed (Legault v. Malacker, (1917) 166 Wisc. 58, 163 N. W. 476, 1 A. L. R. 1109 ; Elliot v. Herz, (1874) 29 Mich. 202). If the statute specifies certain harms, there is no liability for different, though similar damage, in the absence of scienter (Van Etten v. Noyes, (1908) 128 App. Div. 406, 112 N. Y. S. 888; Osincup v. Nichols, (1867) 49 Barb. 145). But cf. Wright v. Pearson, (1869) L. R. 4 Q. B. 582.

${ }^{66}$ (1865) 3 Hurl. \& Colt. 774; (1866) L. R. 1 Ex. 265; (1868) L. R. 3 H. L. 330. 
foreign substances which, although in their natural state containing no serious or unusual potentialities for harm, are accumulated in quantities so great as to create a grave threat of harm should they escape, is liable for such harm in the event of their escape, irrespective of the care and diligence employed to confine them. In that case Lord Blackburn relied heavily upon the rule applicable to the excursions of straying cattle and to personal injuries inflicted by dangerous animals. ${ }^{67}$ Lord Cairns in the house of lords thought "the principles on which this case must be determined appear . . . to be extremely simple". ${ }^{6 s}$ None of the judges regarded the principle as a new one; it was merely an instance of the principle of liability, independent of negligence or any other fault, for the escape of chattels brought on to the land in circumstances which make their escape dangerous to others. ${ }^{69}$

In spite of the position thus taken by the judges in the exchequer chamber and house of lords, efforts have been made to explain this rule on other grounds. Thus, it has been pointed out that the defendants in Rylands v. Fletcher were actually in a position in which they were responsible, on orthodox and established principles, for the acts of the contractors and their servants who had constructed the reservoir from which the

${ }^{67}(1866)$ L. R. 1 Ex. $26 j$.

${ }^{68}(1868)$ L. R. 3 H. L. 330.

${ }^{69} \mathrm{Cf}$. also Judge Augustus Hand in Exner v. Sherman Constr. Co., (1931) 54 Fed. (2) 510, 80 A. L. R. 686: "Furthermore, the imposition of absolute liability is not out of accord with any generai principles of law. As Professor Holdsworth has said: 'The dominant idea of Ang10-Saxon law' was 'that man acts at his peril.' (2 History of English Law, 42. See, also, Pollock on Torts (10th ed.) 15). Accordingly, the earlier forms of action such as trespass and trespass quare clausum fregit allowed recovery for a direct invasion of person or property without regard to fault. After the later action 'sur case' arose, there was a growing tendency to excuse an act causing damage if the defendant was without fault. But, in trespass, fault ordinarily remained a matter of no consequence, and even in cases of damage to the person the early decisions prior to Brown v. Kendall, 6 Cush. (60 Mass.) 292, seemed to have imposed liability where there was no negligence. Dickenson v. Watson, T. Jones, 205: Although liability for injury to the person has not in most instances survived except where there has been fault, there still remains absolute liability for trespasses to real estate and for actionable wrongs committed by servants no matter how carefully they are selected by the master. The extent to which one man in the lawful conduct of his business is liable for injuries to another involves an adjustment of conflicting interests. The solution of the problem in each particular case has never been dependent upon any universal criterion of liability (such as 'fault') applicable to all situations. If damage is inflicted, there ordinarily is liability, in the absence of excuse. When, as here, the defendant, though without fault, has engaged in the perilous activity of storing large quantities of a dangerous explosive for use in his business, we think there is no justification for relieving it of liability, and that the owner of the business, rather than a third person who has no relation to the explosion, other than that of injury, should bear the loss." 
water escaped. ${ }^{70}$ It was conceded that there had been negligence on the part of some of these persons. Again it has been ably contended that liability in this case is merely a unique application of the law of nuisance. ${ }^{71}$ The subsequent adherence of the English courts to the principle developed in Rylands v. Fletcher, however, indicates that here is another instance of conduct carried on at the peril of the actor.

Although in America there were early objections to this aspect of the principle ${ }^{72}$ there has been a noteworthy tendency toward its acceptance ${ }^{7: 3}$ and, indeed, very considerable extension. The rule has been applied in California to substances not imported on to the land, but naturally there. ${ }^{74}$ It has been applied in Kansas to impose liability for harm caused subsequent to the careful confinement and delivery of the substance in its dangerous quantities to a third person. ${ }^{75}$ The rule has been applied to the accumulation of explosives for proper and legitimate purposes which have been accidentally discharged by forces over whom the clefendant has had no control. ${ }^{76}$

${ }^{70}$ See Street, Foundations of Legal Liability, vol. I, at p. 62; J. Smith, "Tort and Absolute Liability" in 30 Harvard Law Review (1917), at pp. 409-10.

${ }^{71}$ Salmond on Torts (ed. 7), at p. 372.

$7^{2} L o s e$ v. Buchanan, (1873) 51 N. Y. 476, 10 Am. Rep. 623; Marshall v. Wclwood, (1876) 38 N. J. L. 339, 20 Am. Rep. 394; Brown v. Collins, (1873) 53 N. H. 442, 16 Am. Rep. 372; Shrezssurry v. Smith, (1853) 12 Cush. 177; Livingston v. Adans, (1828) 8 Cow. (N. Y.) 175 ; Gulf etc. R. Co. v. Oakcs, (1900) 94 Tex. 155, 58 S. W. 999, 52 L. R. A. 293.

${ }^{73}$ Sanderson v. Pennsylvania Coal Co., (1878) 86 Pa. 401, 27 Am. Rep. 711; French v. Center Creek Pozuder M'fg Co., (1913) 173 Mo. App. 220, 158 S. W. 723; Exner v. Sherman Power Constr. Co., (1931) 54 Fed. (2) 510, 80 A. L. R. 686, noted in 45 Harvard Law Review (1932), at p. 594; 80 University of Pennsylvania Law Review, at p. 924; Green v. General Petrolenm Corp., (1928) 205 Calif. 328, 270 Pac. 952, 60 A. L. R. 475 as to which see Carpenter, "The Rule in Green v. General Petroleum Corp." in 5 Southern California Law Review (1932), at p. 263 ; Bradford Glycerine Co. v. St. Marys Woolen M'fg Co., (1899) 60 Ohio St. 560, 54 N. E. 528, 71 Am. St. Rep. 740; Brennan Constr. Co. v. Cumberland, (1907) 29 App. D. C. 554,10 Ann. Cas. 865, 15 L. R. A. (N.S.) 535; Wiltse v. Red Wing, (1906) 99 Minn. 255, 109 N. W. 114; Robb v. Carnegie Bros. \& Co., (1891) 145 Pa. 324, 22 Atl. 649, 14 L. R. A. 329, 27 Am. St. Rep. 694; State Highway Comm. v. Empire Oil \& Ref. Co., (1935) 40 Pac. (2) 355 (Kans.) ; Berry v. Shell Petroleum Co., (1934) 140 Kans. 94, 33 Pac. (2) 953; Brady v. Cox, (1932) 48 S. W. (2) 511 (Tex. Civ. App.), semble.

${ }^{74}$ Green v. General Petroleum Corp. (supra, n. 73).

${ }^{75}$ Berry v. Shell Petroleum Co., (1934) 140 Kans. 94, 33 Pac. (2) 953. A statute in Kansas imposes on oil companies the duty to confine oil and salt water and, at their peril, to prevent their escape. The court, however, based its decision not only on the statute but on the previously adopted common-law rule.

${ }^{76}$ Exner v. Sherman Power Constr. Co. (supra, n. 73). Judge Hand, in this case, relied somewhat upon the analogy of the decisions which impose liability for 


\section{The Place of Liability without Fault in the Law of Tort}

A number of years ago it was suggested by Professor Jeremiah Smith that the principle of liability without fault and the various instances thereof might well be regarded as outside the province of the law of tort. ${ }^{77}$ Notwithstanding the suggestion and the grounds therefor, it has been uniformly regarded otherwise in Anglo-American law. This type of liability, it is submitted, is capable of rationalization as applications of fundamental principles of the law of tort.

There is no compelling reason why the province of tort law should be confined to conduct which involves moral derilection. In fact, it has never been so limited in the common law. There are persuasive reasons for believing that in its origin liability for harm to persons and things in English law was altogether independent of the fault of the defendant. Action at peril seems once to have been the general rule. ${ }^{78}$ It has been by way of growth that the element of moral fault has been injected into tort law as a condition to liability. The inclusion of liability without fault as a part of the law of tort involves no embarrassment so far as analytical

harm to property and person by the accidental miscarriage of carefully conducted blasting operations. It is to be noted that such cases are not within the scope of the present discussion since the harm is directly caused by the deliberate release of the destructive force by a human agency. The unintended character of the resulting harm and the precautions taken by the actor to prevent it, however, make the analogy forceful. See J. Smith, "Liability for Damage to Land by Blasting-The Rule of the Future" in 33 Harvard Law Review (1920), at p. 542.

${ }^{77} \mathrm{~J}$. Smith, "Tort and Absolute Liability" in 30 Harvard Law Review (1917). at pp. $409,421 \mathrm{ff}$.

${ }^{8}$ Sir W. Holdsworth, History of English Law (ed. 3, London, 1923, vol. II, at pp. $50 \mathrm{ff} ; \mathrm{J}$. H. Wigmore, "Responsibility for Tortious Acts: Its History" in 7 Harvard Lazv Review (1894), at pp. 315, 383, 441; Selected Essays on the Law of Torts, at p. 18; J. Smith, "Tort and Absolute Liability" in 30 Harvard Law Review (1917), at pp. 241, 248. With all of which compare N. Isaacs, "Fault and Liability" in 31 Harvard Law Review (1918), at p. 954; and P. H. Winfield, "The Myth of Absolute Liability" in 42 Law Quarterly Review (1926), at p. 37. "Action at peril" is, like the phrase "liability without fault", somewhat misleading. There seems at no time in English law such liability imposed literally. There undoubtedly have always been liability-limiting factors. Thus arbitrary limitations in theories of causation obviously qualify the most rigid doctrine of legal liability. By "action at peril" all that is meant is that moral fault is not a condition to liability in the first instance. Innocent and even highly commendable conduct may become the basis of legal responsibility even though the resulting harm is brought about through forces and events over which the actor has no control. Thus, under the doctrine of respondeat superior, the employment of another to perform service in itself socially desirable, is tortious conduct. Under such an analysis the distinction between vicarious liability and primary liability disappears. 
distinctions are concerned from the law of contract and quasi-contract. ${ }^{79}$ Fault seems no more a necessary ingredient of tort law than of contract law or its absence from quasi-contract.

Legal liability in tort involves four factors: first, the actionable character of the defendant's conduct; second, the character of the plaintiff's injury; third, the causal relation between the two; and fourth, the participation by the plaintiff in bringing about his injury. Liability without fault is subject to analysis in terms of these four factors quite as much as in case of any other type of tortious liability.

(i) As to the tortious character of the defendant's conduct. To become the basis of liability in tort, conduct must contain a threat of harm to others. There is no instance of legal liability in tort at common law based upon conduct which contains no foreseeable potentialities of danger to others. ${ }^{80}$ In the case of intended harms such as assault, battery, false imprisonment, malicious prosecution, and deceit the danger is obvious. The defendant acts for the very purpose of invading the legally protected interests of the plaintiff. ${ }^{81}$ In the case of negligence, the definition of the defendant's conduct indicates the foreseeable character of the resulting harm. In the case of liability without fault, the same element is present. The general propensity of cattle and other domestic animals to stray is emphasized in the cases. Not only is it to be anticipated that cattle will wander from their confinement if possible, but resulting harm from their trespasses is also foreseeable. This, too, is given as one of the grounds for the rule. In a leading case the absence of this factor in the case of dogs and other small animals was the basis given for the distinction as to such animals. "We can easily see why the law should hold the owner of a horse or an ox responsible for trespass; any trespass by those animals must cause some damage, even when the animal is merely wandering about and eating what attracts it. Trespass by a dog is very different; a dog following its natural propensity to stray is not likely to do substantial damage in ordinary circumstances." 82 So, too, it is notorious that wild animals, although confined for many years or even born in captivity, involve a serious threat of harm to others in the event of their escape. The same is true of many activities which involve the accumulation of

${ }^{79}$ See P. H. Winfield, The Law of Tort (Cambridge, 1931), at pp. 215-6, 242.

${ }^{80}$ See F. V. Harper, "The Foreseeability Factor in the Law of Torts" in 7 Notre Dane Lazuyer (1933), at p. 468.

${ }^{81}$ The defendant may be labouring under a mistake as to the identity of the legally protected interests which he invades or as to the existence of the plaintiff's interests. However, he intends the immediate results of his act and the resulting invasion of such outstanding legally protected interests as there may exist.

82 Buckle v. Holmes, [1926] 2 K. B. $125 ; 54$ T. L. R. 89.

5 
large quantities of substances not naturally on land. In fact, all situations in which liability has been imposed under the doctrine of Rylands $\mathrm{v}$. Fletcher involve the accumulation of substances which, because of their nature and quantity, create a definite risk to persons on adjoining land. In all of these situations there remains, in spite of all reasonable precautions, an irreducible minimum of danger, and in this respect the character of the defendant's conduct is tortious to the same extent as in any other type of tort liability. As a matter of accurate analysis, trespass to land and defamation should be classified as additional instances of liability without fault rather than, as is most frequently the case, included among intentional wrongs. In both instances the defendant acts at his peril and may become liable even in the absence of an intention to cause harm or negligence in so doing.

(ii) As to the character of the plaintiff's harm. No difficulty whatever appears at this point. The types of harm for which recovery may be obtained under the principle of liability without fault are all items of recovery in any other area of tort liability. No unique interests are protected under the doctrine of liability without fault. In the case of liability for trespassing animals as well as harm done by wild animals or by the escape of foreign substances accumulated on land, interests in the physical integrity of the person and in property are given legal protection. The range of interests which receive protection under this principle are limited by the same conditions applicable to other cases of tort liability, and no interest is protected here which does not also receive protection under other rules of tort law.

(iii) As to the causal relation between conduct and harm. It has seldom been noted that the general rules of causation apply to all cases of liability without fault in much the same way as in cases involving the negligence of the defendant. ${ }^{83}$ Lord Blackburn pointed out in Rylands v. Fletcher that the defendant was answerable only for "damage which is the natural consequence of its escape". ${ }^{8 t}$ He thereupon added that the land-owner would not be liable in the event the water had escaped from the reservoir by an act of God. A clecision to this effect was subsequently rendered in the exchequer division. $^{\mathrm{s}}$ A few years later immunity was also accorded when the substance on the defendant's premises was shown to have escaped by the wrongful act of a third person whose intervention in so

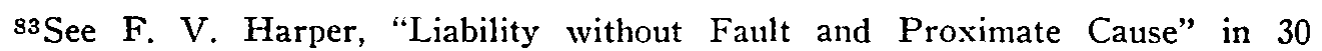
Michigan Law Revicw (1932), at p. 1001.

84(1866) L. R. 1 Ex. 265.

siNicholls v. Marsland, (1875) L. R. 2 Ex. D. 1. 
doing was not the subject of reasonable foresight. ${ }^{80}$ So, too, the unforeseeable intervention of an animal in causing the escape relieved the defendant from liability. ${ }^{37}$ In the case of liability for trespassing animals, it is held that cattle driven on to the plaintiff's land by an intermeddling stranger does not make the possessor of the cattle liable, ${ }^{88}$ although if the stranger releases the cattle and they subsequently wander on to the plaintiff's land the possessor is liable. ${ }^{89}$ While the possessor of domestic animals is liable for all harm directly attributable to the trespass of his animals, ${ }^{90}$ an unforeseeable intervening force for which he is not responsible will not increase the extent of his responsibility. ${ }^{91}$ Again, he who keeps a wild animal is responsible only within the ambit fixed by orthodox rules of legal causation. The plaintiff's harm must be attributable both to the fact of the defendant's possession and the vicious propensities of the animal. Thus, a wild animal which is indigenous to the locality will not subject his captor to liability for injury inflicted by it after it has escaped and again become a part of the wild life of the particular locality. ${ }^{92}$ So, too, harm done by the escape of a wild animal which does not result from its wild or vicious nature does not make liable the person from whose possession or custody it escaped. ${ }^{93}$

${ }^{86} B o x$ v. $J u b b,(1879)$ L. R. 4 Ex. D. 76 . The principle of this case was subsequently affirmed by the house of lords in Rickards v. Lothian, [1913] A. C. 263.

${ }^{87}$ Carstairs v. Taylor, (1871) L. R. 6 Ex. 217, per Kelly, C. B.

${ }^{88}$ Hartford v. Brady, (1874) 114 Mass. 466; 19 Am. Rep. 377.

${ }^{89}$ Noyes v. Colby, (1855) 30 N. H. 143.

90Theyer v. Purnell, [1918] 2 K. B. 333 (defendant's sheep, while trespassing on plaintiff's land, infected his flocks. Defendant held liable whether or not he knew or should have known that his sheep were diseased); Ellis v. Loftus Iron Co., (1874) L. R. 10 C. P. 10 (defendant's stallion, while trespassing on plaintiff's land, bit his mare); Crawford v. Willians, (1878) 48 Iowa 247 (defendant's worthless bull impregnated plaintiff's thoroughbred cow).

91 Hollenbeck v. Johnson, (1894) 79 Hun. 499; 29 N. Y. S. 945 (defendant's cow strayed on to plaintiff's premises and crushed the cover of an old cistern into which the plaintiff, without negligence, fell. Defendant was liable for the trespass and property damage although not liable for plaintiff's personal injuries.) The general principle of liability for harm by trespassing animals, includes harm to the person as well as damage to property and the lack of notice of the owner of the animal of its vicious nature is immaterial. See 32 Harvard Law Review (1919), at p. 420 , collecting cases.

92Mitchil v. Alestree, (1676) 1 Ventris 295; Bowlston v. Hardy, 2 Croke Eliz. 546; Brady v. Warren, [1900] 2 Ir. Rep. 632; Tentative Restatement of Torts, $\S 508$.

93Scribner v. Kelley, (1862) 38 Barb. 14; Bostock Ferari Amusement Co. v. Brocksmith, (1905) 34 Ind. App. 566, 73 N. E. 281, 107 Am. St. Rep. 260; Marsh v. Koons. (1908) 78 Ohio St. 68, 84 N. E. 599, 16 L. R. A. (N.S.) 647, 125 Am. St. Rep. 688, 14 Ann. Cas. 621. 
All of these rules indicate that not only the character of the plaintiff's injury but the manner in which he sustained it must be the materialization of the general type of risk which made the defendant's conduct actionable, and in this respect liability without fault follows the same patterns as liability for tort in other respects.

(iv) As to the plaintiff's participation in causing his harm. In all phases of tort liability the plaintiff may be disentitled to recover from one whose tortious conduct has caused an actionable injury. This principle manifests itself in a number of rules. He who consents cannot complain of battery or trespass. He who participates in conduct prohibited by law cannot recover for personal injuries. $\mathrm{He}$ who by his own negligence contributes to his injury cannot, save in exceptional situations, recover from a negligent defendant. He who knowingly subjects himself to certain risks cannot claim protection therefrom by the person responsible for the creation of the risk. The same principle is apparent in cases of liability without fault.

Where statutes have so modified the common law as to require a landowner to fence out his neighbour's cattle, ${ }^{04}$ his failure to do so bars a recovery for their intrusion, and no case has ever been found in which one who consented to his neighbour's cattle pasturing on his land recovered the loss caused thereby. In the case of personal injuries by wild animals, while that form of contributory negligence which consists of mere inadvertence to the danger will not affect a plaintiff's right to recover, ${ }^{95}$ the deliberate exposure by him to the risk of harm will prevent recovery ${ }^{96}$ This is analogous to the doctrine of assumption of risk in negligence cases and the administration of the rule follows closely that observable in other cases of liability. So, too, in situations to which the rule of Rylands $\mathrm{v}$. Fletcher is applicable, what Lord Blackburn called the "plaintiff's default" will bar recovery. This, too, may be likened to the doctrine of assumption of the risk and is to be found in an interesting case in which both plaintiff and defendant had accumulated the same dangerous substance on their

${ }^{94}$ See supra, n. 40.

${ }^{95}$ Smith v. Pelah, (1747) 2 Strange 1264; Sandy v. Bushey, (1925) $124 \mathrm{Me}$. 320 ; Fake v. Addicks, (1890) 45 Minn. 37; Muller v. McKesson, (1878) 73 N. X. 195 ; Copley v. Wills, (1913) 152 S. W. 830 (Tex. Civ. App.).

${ }^{90}$ Muller v. McKesson, (1878) 73 N. Y. 195; Ervin v. Woodruff, (1907) 119 App. Div. 603, 103 N. Y. S. 1051; Guzzi v. New York Zoological Soc., (1920) 192 App. Div. 263, 182 N. Y. S. 257 ; 233 N. Y. 511, 135 N. E. 897; Opelt v. Al. G. Barnes, (1919) 41 Calif. App. 776, 183 Pac. 241 ; Lehnhard v. Robertson, (1917) 176 Ky. 322, 195 S. W. 441 ; Marlor v. Ball, (1900) 16 T. L. R. 239. 
land. The escape from the one was held not actionable by the other. ${ }^{07}$ Both parties had here engaged in the same type of tortious though socially commendable conduct, and neither could complain because the other's activity had resulted in harm to him.

\section{SumMary}

In conclusion, two generalizations seem justifiable with respect to liability in Anglo-American law for harm done by chattels.

First, the governing principle in all cases is strict liability or liability without fault. This proposition, of course, is qualified by certain arbitrary limitations to the applicability of the principle. Thus, the general principle does not apply to trespass of dogs and other small animals; liability may be imposed, however, if the particular circumstances of a case disclose the possessor of such animals to be guilty of negligence. So too, while certain animals, as for instance, bees, are not classed as wild and vicious beasts which the possessor keeps at his peril, nevertheless a particular possessor of bees may be liable for injuries to persons or things if he is negligent in the manner and place of keeping.

Second, the general principle of strict liability is properly regarded as liability ex delicto. It is not based upon a fiction of fault nor is it a spurious form of vicarious liability. On the other hand, it need not be regarded as sui generis. All the basic rational equipment of tort law is applicable to this form of liability. All aspects of the application of the principle may be subsumed under the major doctrines of liability for tort.

Indiana University School of Law.

Fowler V. HARPER

${ }^{97}$ Eastern etc. Tel. Co. v. Cape Town Tramways Co., Lt'd., [1902] A. C. 381, and see Lake Shore etc. R. Co. v. Chicago etc. R. Co., (1910) 48 Ind. App. 584, 92 N. E. 989,95 N. E. 596. 